\title{
PREDIKSI EROSI DAN PERENCANAAN KONSERVASI TANAH PADA DAERAH ALIRAN SUNGAI JANGA KABUPATEN KARANGASEM, BALI
}

\author{
Julianus Jeksen $^{11}, 1$ Wayan Diara dan Wiyanti ${ }^{3)}$ \\ 1)Jurusan Agroekoteknologi Fakultas Pertanian Universitas Flores, 2)Jurusan Ilmu Tanah Fakultas \\ Pertanian Universitas Udayana
}

\begin{abstract}
Erosion Prediction and Soil Conservation Plan on Janga Flow River Area in Karangasem Bali

Erosion prediction on janga flow river area at karangasem district used USLE ( Universal Soil Loss Equation ). This research conducted to know the large erotion on janga flow river area and conservation treatment on unit larger erosion area of permitted erosion to concern on the class of ability area. Based on slope map compilation, used area map and soil variety map on research area was founded L6 unit area. The large erosion predict on janga flow river area between 0,829 to $1.109,208$ ton $/ \mathrm{ha} / \mathrm{th}$.

Low erosion in area unit 1,3,5,6,7,and 9 located on downstream of flow river area. Be on the process of erosion on area unit 11 and 13 located on mid flow river area. High erosion in area unit 14 and 16 located on upper reaches flow river area. Lowest erosion found in area unit 1,3,5,6,7,9,11 and larger erosion of permitted erosion located in area unit 10,13,14,15, and 16 need to soil conservation treatment. Applicable Soil conservation treatment is increasing the density of crops and improve terrace construction and by added used organic substance and cultivation crop
\end{abstract}

Keyword: Erosion prediction, soil conservation

\section{PENDAHULUAN}

Sebagai suatu sistem dinamis, tanah akan selalu mengalami perubahan - perubahan yaitu fisik, kimia ataupun biologi tanahnya. Perubahan - perubahan ini terutama karena pengaruh berbagai unsur iklim, tetapi tidak sedikit pula yang dipercepat oleh tindkan atau peiiakuan manusia. Kerusakan tubuh tanah yang diakibatkan berfangsungnya perubahan perubahan berlebihan misalnya kerusakan dengan lenyapnya lapisan olah tanah, peristiwa ini dikenal dengan erosi (Sutedjo, 2002).

Menurut Hardjowigeno (2003) erosi diartikan suatu proses dimana tanah dihancurkan dan kemudian dipindahkan kelempat lain oleh kekuatan air, angin atau gravitasi. Di Indonesia erosi yang terpenting adalah yang disebabkan oleh air. Menurut Arsyad (1989) beberapa faktor yang mempengaruhi besarnya erosi adalah curah hujan, si fat - sifat tanah, lereng, vegetasi, sebagian sifat - sifat tanah yaitu kesuburan tanah, ketahanan agregat, dan kapasitas infiltrasi, serta satu unsur topografi yaitu panjang lereng, sedangkan faktor-faktor yang tidak dapat dikendalikan oleh manusia adalah iklim, tipe tanah dan kecuraman lereng.

Erosi dapat menyebabkan : 1) hilangnya lapisan atas tanah yang subur yang akan mengakibatkan terjadinya penurunan produkti vitas, 2) berkurangnya kemampuan tanah untuk menyerap dan menahan air (Diara, dkk. 2001). Di alam erosi terjadi secara terus menerus dan tidak mungkin meniadakan erosi pada tanah-tanah yang diusahakan untuk pertanian terutama pada tanah yang berlereng. Untuk mempertahankan produkti vitas tanah dan menghindari kerusakan yang Iebih parah, maka perlu diketahui besarnya erosi yang terjadi dan selanjutnya melakukan tindakan konservasi tanah pada daerah yang erosinya Iebih besar dari pada erosi yang diperbolehkan.

DAS Janga merupakan salah' satu DAS yang melewati dua Kecamatan, yaitu Kecamatan Abang dan Kecamatan Karangasem. Bagian hulu dari DAS Janga yang masih berupa hutan sangat besar pengaruhnya bagi lahan pertanian dan pemukiman penduduk yang ada di bagian hilir terutama dalam hal ketersediaan air bersih. Sungai Janga sendiri berperan penting bagi masyarakat di dua Kecamatan tersebut terutama Desa Padang Kerta, Kelurahan Karangasem dan Kelurahan Subagan. Peran tersebut dapat berupa untuk pemenuhan untuk pemenuhan kebutuhan seharihari maupun sebagai sumber irigasi areal pertanian mereka.

Dari hasil survei lapangan ternyata terdapat perubahan penggunaan lahan, seperti tegalan berubah menjadi areal pertambangan pasir dan persawahan berubah menjadi pemukiman. Perubahan penggunaan lahan ini terdapat di Desa Padang Kerta Kelurahan Karangasem, sehingga perlu dilakukan pengelolaan dan dilestarikan untuk menghindari terjadinya kerusakan dan degradasi DAS yang Iebih parah. Dalam pengelolaan dan pelestarian suatu DAS, selain dapat menggunakan prediksi erosi juga harus memperhatikan kelas kemampuan lahan. 
Berdasarkan hal tersebut diatas, maka penulis berkeinginan untuk memprediksi dan meneliti besarnya erosi yang terjadi pada DAS Janga dengan menggunakan metode USLE (Universal Soil Loss Equation) serta merencanakan tindakan konservasi tanah apabila erosi yang terjadi lebih besar daripada erosi yang diperbolehkan.

Penelitian ini bertujuan untuk menduga besarnya erosi yang terjadi pada daerah aliran sungai Janga Kabupaten Karangasem dengan menggunakan metode USLE, dan mereneanakan tindakan konservasi tanah pada unit-unit lahan yang erosinya lebih besar dari erosi yang diperbolehkan dengan memperhatikan kelas kemampuan lahan.

\section{BAHAN DAN METODE}

Penelitian ini dilaksanakan di DAS Janga Kabupaten Karangasem. Secara geografis DAS Janga teiietak antara $\mathrm{O}^{\circ} 22^{\prime} 3 \mathrm{O}^{\prime \prime}$ sampai 08²7'30" Lintang Selatan dan antara
115³2'30" sampai 115³7'30" Bujur Timur. Daerah penelitian secara administratif berbatasan dengan Selat Lombok di bagian Timur, Kecamatan Bebandem di bagian Barat, Kecamatan Abang di bagian Utara dan Selat Badung di bagian Selatan. Luas daerah penelitian adalah $1.626,5115$ ha atau $16,26 . \mathrm{km}^{2}$.

Bahan dan alat yang digunakan dalam penelitian ini adalah peta lereng, peta penggunaan lahan yang diperoleh dari peta rupa bumi skala 1 : 25000 , peta jenis tanah skala 1 : 50000 , dan data iklim Penentuan unit lahan berdasarkan kompilasi dari peta lereng, peta penggunaan lahan dan peta jenis tanah masing-masing skala $1: 25$ 000. Lahan yang mempunyai kesamaan lereng, penggunaan iahan, dan jenis tanah dimasukkan atau digolongkan ke dalam satu unit lahan. Satu unit lahan di ambil satu sampel. Jumlah sampel tanah yang di ambil dalam penehtian sebanyak 12 sampel. Unit lahan daerah penelitain disajikan dalam Tabel 2 dan sebarannya di lapangan disajikan pada peta unit lahan.

Tabel 2. Unit lahan daerah penelitian

\begin{tabular}{cclc}
\hline $\begin{array}{c}\text { Unit } \\
\text { Lahan }\end{array}$ & Kemiringan Lereng & \multicolumn{1}{c}{ Penggunaan Lahan } & Jents Tanah \\
\hline 1 & $\mathbf{0}-3 \%$ & Sawah irigasi & Andisol \\
2 & $\mathbf{3 - 8} \%$ & Sawah Irigasi & Andisol \\
3 & $\mathbf{3 - 8 \%}$ & Kebun campuran & Andisoi \\
4 & $\mathbf{3 - 8 \%}$ & Tegalan & Andisol \\
5 & $8-15 \%$ & Sawah Irigasi & Andisol \\
6 & $8-15 \%$ & Kebun campuran & Andisol \\
7 & $8-15 \%$ & Tegalan & Andisol \\
$\mathbf{8}$ & $15-30 \%$ & Sawah irigasi & Andisol \\
9 & $15-30 \%$ & Kebun campuran & Andisol \\
10 & $15-30 \%$ & Tegalan & Andisol \\
11 & $30-45 \%$ & Tegalan & Andisol \\
12 & $30-45 \%$ & Kebun campuran & Andisol \\
\hline
\end{tabular}

Parameter-parameter yang diamati di lapangan meliputi panjang iereng di ukur dengan menggunakan meteran, kemiringan lereng di ukur dengan menggunakan abney level, kedalaman solum tanah di ukur dengan menggunakan bor tanah sedangkan struktur tanah, jenis vegetasi, kerapatan vegetasi, drainase, kerikil/batuan dan tindakan konservasi tanah diketahui melalui pengamatan langsung.

Analisis tanah dilakukan di Laboratorium Tanah Fakultas Pertanian Universitas Udayana. Analisis tanah yang dilakukan yaitu penetapan tekstur tanah dengan metode pipet, kandungan bahan organik dengan metode Walkiey dan Black, berat volume tanah dengan metode ring sampel, penetapan permeabilitas tanah dengan metode De Booth berdasarkan hukum Darcy, salinitas di ukur dengan menggunakan conduktor meter.

Prediksi erosi dilakukan dengan metode USLE (Universal Soil Loss Equation) yang dibuat oleh Wischmeier dan Smith (1978 dalam Arsyad 1989) dengan bentuk persamaan sebagai berikut:

$$
\mathrm{A} \quad=\mathrm{R} \times \mathrm{K} \times \mathrm{L} \mathrm{S} \times \mathrm{CP}
$$

A adalah besarnya erosi (ton/ha/tahun), $\mathrm{R}$ adalah indeks erosivitas hujan (ton $/ \mathrm{ha} / \mathrm{cm}$ hujan), $\mathrm{K}$ adalah erodibilitas tanah, LS adalah panajng lereng dan kemiringan iereng, $\mathrm{CP}$ adalah faktor tanaman dan faktor pengelolaan lahan.

\section{Indeks Erosivitas Hujan}

Indeks erosivitas hujan dihitung menggunakan rumus Bols (1978 dalam Arsyad, 1989), yaitu : 


$$
\begin{aligned}
& \mathrm{R}=6,119(\mathrm{RAIN})^{1.21}{\text { (DAYS })^{-0.47}}^{(\mathrm{MAXP})^{0}-53}
\end{aligned}
$$

$\mathrm{R}$ adalah indeks erosivitas hujan bulanan, RAIN adalah curah hujan rata-rata bulanan dalam centimeter, DAYS adalah jumlah hari hujan rata-rata perbulan, dan MAXP adalah curah hujan maksimum selama 24 jam dalam bulan bersangkutan. $\mathrm{R}$ tahunan didapat dari jumlah $\mathrm{R}$ bulanan.

Selanjutnya untuk mengetahui daerah penyebaran curah hujan di hitung dengan menggunakan metode polygon theisein

\section{Erodibilitas Tanah}

Erodibilitas tanah merupakan nilai yang menunjukkan mudah tidaknya tanah tererosi. Erodibilitas tanah dihitung berdasarkan persamaan Wischmeier dan Smith (1978 daiam Arsyad, 1989) yaitu :

$100 \mathrm{~K}=1,292\left\{2,1 \mathrm{M}^{\mathrm{U} 4}\left(10^{\prime \prime}\right)(12-\mathrm{a})+3,25\right.$

$(\mathrm{b}-2)+2,5(\mathrm{c}-3)\}$

$\mathrm{K}$ adalah erodibilitas tanah, $\mathrm{M}$ adalah (\% pasir halus dan \% debu) x (100 - \% liat) dan a adalah bahan organik, b adalah kelas struktur tanah, c adalah kelas permeabilitas tanah.

\section{Panjang dan Kemiringan Lereng}

Untuk menghitung faktor panjang dan kemiringan lereng (LS), menggunakan persamaan Wischmeier dan Smith (1978 daiam Arsyad, 1989) yaitu :

$$
\mathrm{LS}=\overline{\mathrm{VL}}\left(0,00138 \mathrm{~S}^{2}+0,00965 \mathrm{~S}+0,0138\right)
$$

LS adalah nilai faktor panjang dan kemiringan lereng, L adalah panjang lereng $(\mathrm{m}), \mathrm{S}$ adalah kemiringan lereng $\{\%$ ).

Faktor Tanaman dan Pengelolaan Lahan (CP) Penentuan niali CP dilakukan dengan pendekatan antara keadaan di lapangan dengan hasil peneiitian dari Pusat Peneiitian Tanah Bogor (1973-1981 dalam Arsyad 1989) (Lampiran 8.)

\section{Erosi yang Dapat Diperbolehkan (Edp)}

Nilai batas erosi yang dapat diperbolehkan (Edp) adalah nilai laju erosi yang tidak melebihi laju pembentukan tanah. Pada peneiitian ini, Edp dihitung dengan persamaan Hammer (Hammer, 1981 dalam Arsyad, 1989) yaitu :

Edp $=\frac{\text { Kedalaman tanah efektif }(\mathrm{mm}) \times \text { Faktor kedalaman }}{\text { Umur guna tanah }}$

Kedalaman tanah efektif diperoleh dengan pengukuran di lapangan, yang diukur sampai kedalaman bahan induk (lapisan yang menghambat pertumbuhan tanaman). Faktor kedalaman tanah adalah faktor menurunnya kualitas tanah, diperoleh dari tabel nilai faktor kedalaman 30 sub - order tanah (Arsyad, 1989). Umur guna tanah adalah jangka waktu yang cukup (tahun) untuk memelihara kelestarian tanah. Pada peneiitian ini menggunakan umur guna 300 tahun.

\section{Perencanaan Konservasi Tanah}

Perencanaan konservasi tanah didasarkan atas perbandingan antara erosi yang terjadi dengan erosi yang dapat diperbolehkan (Edp). Bila erosi yang terjadi iebih besar dari Edp, maka dilakukan

perencanaan konservasi dengan jalan merubah nilai faktor tanaman dan pengelolaan lahan (CP) dengan melihat kelas kemampuan lahan pada DAS Janga, sehingga erosi yang terjadi Iebih kecil atau sama dengan erosi yang dapat diperbolehkan.

\section{Klasifikasi Kemampuan Lahan}

Sistem klasifikasi kemampuan lahan yang di.gunakan dalam peneiitian ini adalah sistem klasifikasi yang dikemukakan oleh Hockensmith dan Steel (1943) dan Klingebiel dan Montgomery (1973 dalam_Arsyad, 1989) menurut sistem ini, lahan dikelompokkan dalam delapan kelas kemampuan lahan dan subklas dengan masing>masing faktor penghambat yang menjadi pembatasnya. Pengelompokan dalam kelas didasarkan atas intensitas faktor penghambat. Tanah dikelompokkan ke dalam delapan kelas yang ditandai dengan angka Romawi I sampai VIII. Pengelompokkan Terdapat beberapa jenis faktor pembatas yaitu ancaman erosi (e), keadaan drainase atau kelebihan air (w), daerah perakaran (s), dan iklim (c). Data yang diperlukan untuk menentukan kelas kemampuan lahan adalah lereng permukaan, kepekaan erosi, tingkat erosi, kedaiaman tanah, tekstur tanah, permeabilitas tanah, drainase, kerikil/batuan, ancaman banjir dan salinitas. Kriteria klasifikasi kemampuan lahan disajikan dalam Tabel 3. 
Tabel 3. Kriteria klasifikasi kemampuan Iahan (Arsyad, 1989)

\begin{tabular}{|c|c|c|c|c|c|c|c|c|}
\hline \multirow{2}{*}{$\begin{array}{l}\text { Faktor } \\
\text { Pembatas }\end{array}$} & \multicolumn{8}{|c|}{ Kelas Kemampuan Lahan } \\
\hline & $\mathrm{I}$ & II & III & IV & $\mathrm{V}$ & VI & VII & VIII \\
\hline \multirow{2}{*}{$\begin{array}{l}\text { Lereng Permukaan } \\
\text { Kepekaan erosi }\end{array}$} & A & $\mathrm{B}$ & $\mathrm{C}$ & $\mathrm{D}$ & A & $\mathrm{E}$ & $\mathrm{F}$ & $\mathrm{G}$ \\
\hline & $\begin{array}{l}\text { KE1 } \\
\text { KE2 }\end{array}$ & KE3 & $\begin{array}{l}\text { KE4 } \\
\text { K35 }\end{array}$ & KE6 & $(*)$ & $(*)$ & $(*)$ & $(*)$ \\
\hline Tingkat Erosi & EO & El & E2 & E3 & $(* *)$ & E4 & E5 & $(*)$ \\
\hline Kedalaman Tanah & $\mathrm{kO}$ & $\mathrm{kl}$ & $\mathrm{k} 2$ & $\mathrm{~K} 2$ & $(*)$ & $\mathrm{k} 3$ & $(\dot{*})$ & $(*)$ \\
\hline \multirow[t]{4}{*}{ Tekstur Lapisan atas } & $\mathrm{tl}$ & $\mathrm{tl}$ & $\mathrm{tl}$ & $\mathrm{Tl}$ & $(*)$ & $\mathrm{tl}$ & $\mathrm{tl}$ & t5 \\
\hline & $\mathrm{t} 2$ & $a$ & $\mathrm{t} 2$ & $\mathrm{~T} 2$ & & $\mathrm{t} 2 \cdot$ & $\mathrm{t} 2$ & \\
\hline & $\mathrm{t} 3$ & $\mathrm{t} 3$ & $\mathrm{t} 3$ & $\mathrm{~T} 3$ & & $\mathrm{t} 3$ & $\mathrm{t} 3$ & \\
\hline & $\mathrm{t} 4$ & $\mathrm{t} 4$ & $\mathrm{t} 4$ & $\mathrm{~T} 4$ & & $\mathrm{t} 4$ & $\mathrm{t} 4$ & \\
\hline Tekstur Lapisan Bawah & sda & sda & Sda & Sda & $(*)$ & Sda & Sda & $\mathrm{t} 5$ \\
\hline \multirow[t]{2}{*}{ Permeabilitas Tanah } & $\mathrm{P} 2$ & $\mathrm{P} 2$ & $\mathrm{P} 2$ & P2 & $\mathrm{Pi}$ & $(*)$ & $(*)$ & P5 \\
\hline & P3 & P3 & $\begin{array}{l}\text { P3 } \\
\text { P4 }\end{array}$ & $\begin{array}{l}\text { P3 } \\
\text { P4 }\end{array}$ & & & & \\
\hline Drainase & dl & $\mathrm{d} 2$ & d3 & D4 & d5 & $(* *)$ & $(* *)$ & $\mathrm{dO}$ \\
\hline Kerikil/Batuan & bl & b2 & b3 & B4 & b5 & $n$ & $"(*)$ & bO \\
\hline Ancaman Banjir & 00 & 01 & 02 & 03 & 04 & $(+*)$ & $(* *)$ & $(*)$ \\
\hline Salinitas $(* * *)$ & go & gl & $\&$ & g3 & $(* *)$ & g3 & $(*)$ & $(*)$ \\
\hline
\end{tabular}

Catalan :

$$
\begin{array}{ll}
(*) & \text { : dapat mempunyai sembarang; sifat } \\
(* *) & \text { : tidak berlaku } \\
(* * *) & \text { : umumnya terdapat di daerah beriklim kering }
\end{array}
$$

Keterangan:

Kecuraman lereng, panjang lereng dan bentuk lereng semuanya mempengaruhi besarnya erosi dan aliran permukaan.

1. Kecuraman lereng dikelompokkan sebagai berikut:

$$
\begin{array}{ll}
\text { A } & : 0-3 \% \text { (datar) } \\
\text { B } & : 3-8 \% \text { (landai atau berombak) } \\
\text { C } & : 8-15 \% \text { (agak miring atau } \\
& \text { bergelombang) } \\
\text { D } & : 15-30 \% \text { (miring atau berbukit) } \\
\text { E } & : 30-45 \% \text { (agak curam) } \\
\text { F } & : 45-65 \% \text { (curam) } \\
\text { G } & :>65 \% \text { (sangat curam) }
\end{array}
$$

2. Kepekaan Erosi tanah (nilai K) dikelompokkan sebagai berikut:

$\mathrm{KEi}:$ : 0,00-0,1 (sangat rendah)

$\mathrm{KE}_{2}: \mathbf{0 , 1 1}-0,2$ (rendah)

$\mathrm{KE}_{3}: 0,21-0,3$ (sedang)

$\mathrm{KE}_{4}:$ : 0,31-0,4 (agak tinggi)

$\mathrm{KE}_{5}: 0,41-0,5$ (tinggi)

$\mathrm{KE}_{6}: 0,51-0,6$ (sangat tinggi)

3. Kerusakan erosi yang telah terjadi dikelompokkan sebagai berikut:

$\mathrm{e}_{0} \quad$ : tidak ada erosi

$\mathrm{e}_{1}:<25 \%$ lapisan atas hilang (ringan)

$\mathrm{e}_{2}: 25-75 \%$ lapisan atas hilang (sedang)

$e_{3}:>75 \%$ lapisan atas sampai $<25 \%$. lapisan bawah hilang (agak berat)

$e_{4} \quad:>25 \%$ lapisan bawah hilang (berat)

$\mathrm{e}_{5} \quad$ : erosi parit (sangat berat)
4. Kedalaman tanah efektif adalah kedalaman tanah yang baik bagi pertumbuhan akar tanaman yaitu sampai pada lapisan yang tidak dapat ditembus oieh akar tanaman. Kedalaman efektif tanah dapat diklasifikasikan sebagai berikut:

$\mathrm{K}_{\mathrm{o}}:>90 \mathrm{~cm}$ (dalam)

$\mathrm{K}, \quad: 90-50 \mathrm{~cm}$ (sedang)

$\mathrm{K}_{2}: 50-25 \mathrm{~cm}$ (dangkal)

$\mathrm{K}_{3}:<25 \mathrm{~cm}$ (sangat dangkal)

5,-. Tekstur tanah adalah salah satu faktor penting yang mempengaruhi kapasitas tanah untuk menahan air dan permebialitas tanah serta berbagai sifat fisik dan kimia tanah lainnya. Untuk menentukanklasifikasi kemampuan lahan tekstur lapisan atas tanah $(0-30 \mathrm{~cm})$ dan lapian bawah $(30-60 \mathrm{~cm})$ dikelompokkan sebagai berkut:

$\mathbf{T}_{\text {| }}$ : tekstur halus (liat berpasir. Hat berdebu dan liat)

$\mathbf{T}_{2}$ : tekstur agak halus (liat berpasir, lempung berniat dan lempung liat berdebu)

$\mathrm{T}_{3}$ : tekstur sedang (lempung, lempung berdebu dan debu)

$\mathbf{T}_{4}$ : tekstur agak kasar (lempung berpasir halus, lempung berpasir sangat halus)

$\mathbf{T}_{5}$ : tekstur kasar ( pasir berlempung dan pasir)

6. Permebialitas (P) tanah dapat dikelompokkan sebagai berikut:

$\mathrm{Pi}:<0,5 \mathrm{~cm} / \mathrm{jam}$ (lambat) 
menyebabkan terjadinya erosi yang tinggi. Hal ini juga didukung oleh pendapat Arsyad (1989) bahwa di daerah tropis seperti Indonesia, faktor iklim yang paling besar pengaruhnya terhadap erosi adalah hujan. Selanjutnya Utomo (1987) mengatakan bahwa penghancuran agregat tanah terjadi karena pukulan air hujan dan kikisan air limpasan permukaan. Intensitas dan jumlah curah hujan yang tinggi memiliki energi kinetik yang besar sehingga kemampuan untuk mendispersi agregat-agregat tanah meningkat.
Pecahnya agregat tanah menjadi partikel. partikel tanah yang kecil dan halus menyebabkan tanah menjadi mudah terangkut dan dihayutkan ketika berlangsung aliran permukaan, sebagian akan mengikuti air yang terinfiltrasi dan bagian ini akan dapat menyumbat pori-pori tanah sehingga kapasitas infiltrasi tanah menurun berkurangnya infiltrasi menyebabkan jumlah dan kecepatan aliran permukaan (run off) meningkat sehingga erosivitas hujan menjadi semakin tinggi.

Tabel 6. Indeks erosi vitas hujan stasiun hujan Bebandem

\begin{tabular}{clcccc}
\hline${ }^{N}$ NO & $\begin{array}{c}\text { D oiilan } \\
1\end{array}$ & $\begin{array}{c}\text { Curah hujan } \\
(\mathbf{c m})\end{array}$ & $\begin{array}{c}\text { Hari } \\
\text { hujan }\end{array}$ & $\begin{array}{c}\text { Hujan maks }(\mathbf{c m} / \mathbf{2 4} \\
\text { jam) }\end{array}$ & Erosivitas (ton/ha/cm) \\
2 & Februari & 48,3 & 13 & 20.1 & 980,39 \\
3 & Maret & 40,9 & $\mathbf{1 4}$ & 14,14 & 648,81 \\
4 & April & 15,6 & $\mathbf{1 0}$ & 9,8 & 335,01 \\
5 & Mei & 8,6 & 6 & 9,9 & 250,62 \\
6 & Juni & 5,6 & 5 & 9,2 & 125,81 \\
7 & Juli & 3,5 & 4 & 9,2 & 83,14 \\
8 & Agustus & 3 & 3 & 2,7 & 26,45 \\
9 & September & 7,8 & 4 & 2,7 & 23,35 \\
10 & Oktober & 15,2 & 6 & 5,4 & 93,61 \\
11 & November & 17,9 & 9 & 10,4 & 245,48 \\
12 & Desember & 29,1 & 11 & 8,9 & 227,67 \\
& Total & $\mathbf{2 2 0 , 3}$ & 89 & 9,6 & 388,28 \\
\multicolumn{7}{c}{ Rata-rata } & $\mathbf{1 8 , 3 6}$ & 7,42 & 112,7 & $\mathbf{3 4 2 8 , 6 2}$ \\
\hline
\end{tabular}

\section{Erodibiiitas Tanah (K)}

Berdasarkan hasil perhitungan indeks erodibiiitas tanah (K) dengan menggunakan persamaan Wischmeier dan Smith (1978), maka diperoleh indeks erodibiiitas tanah di daerah. penelitian berkisar antara 0,05 sampai 0,47 (Tabel 7). Nilai erodibiiitas tanah ini tergolong sangat rendah sampai tinggi berdasarkan klasifikasi nilai erodibiiitas Dangler dan El Swaify (1975 dalam Arsyad, 1989). Nilai erodibiiitas tanah yang sangat rendah terdapat pada unit lahan 7. Nilai erodibiiitas tanah yang rendah terdapat pada unit lahan 4,6,8,10,11 dan 12. Nilai erodibiiitas tanah yang sedang terdapat pada unit iahan 1. Nilai erodibiiitas tanah agak tinggi terdapat pada unit lahan 2,3 dan 9. Nilai erodibiiitas tanah yang tinggi terdapat pada unit lahan 5 .

Erodibiiitas tanah yang dinyatakan sebagai kepekaan tanah terhadap erosi atau mudah tidaknya tanah tererosikan merupakan interaksi dari komponen tekstur, struktur, kandungan bahan organik dan permeabiiitas tanah (Utomo, 1987). Tingginya nilai erodibiiitas pada unit-unit lahan di daerah penelitian disebabkan oleh persentase debu dan pasir halus yang tinggi. Fraksi debu dan pasir mempunyai daya ikat yang rendah sehingga siitit membentuk struktur yang mantap dan mudah terdispersi oleh pukulan air hujan maka lebih peka terhadap erosi. Rendahnya bahan organik juga menyebabkan tingginya nilai erodibiiitas tanah, karena bahan organik berperan penting dalam memantapkan agregat tanah, memperbaiki struktur tanah dan mempunyai daya serap dan menahan air tanah yang cukup tinggi. Arsyad, (1989) mengemukakan bahwa bahan organik penting peranannya dalam menstabilkan struktur tanah. Bahan organik yang belum lapuk (seresah) yang menutup permukaan tanah seperti daun-daun dan ranting, dapat melindungi tanah dari dispersi tumbukan butir-butir hujan yang jatuh. selain itu mulsa dapat menghambat kecepatan aliran permukaan, mengurangi daya kikis dan kapasitas angkut aliran permukaan. Bahan organik yang mengalami pelapukan mempunyai kemampuan untuk menyerap dan menahan air yang tinggi sehingga meningkatkan kapasitas infiltrasi. 
Tabel 7. Hasif perhitungan faktor erodibilitas tanah (K)

\begin{tabular}{|c|c|c|c|c|c|c|c|}
\hline $\begin{array}{c}\text { Unit } \\
\text { Lahan }\end{array}$ & $\begin{array}{c}\text { Debu + Pasir } \\
\text { halus }(\%)\end{array}$ & Liat $\%$ & $\begin{array}{c}\text { BO } \\
\%\end{array}$ & $\begin{array}{c}\text { Kelas } \\
\text { Struktur }\end{array}$ & $\begin{array}{c}\text { Kelas } \\
\text { Permeabilitas }\end{array}$ & Nilai $K$ & Ket \\
\hline 1 & 38,719 & 16,21 & 2,82 & 3 & 1 & 0,228 & Sedang \\
\hline 2 & 44,74 & 16,74 & 2,18 & 2 & 4 & 0,346 & $\begin{array}{l}\text { Agak } \\
\text { tinggi }\end{array}$ \\
\hline 3 & 33,944 & 19,76 & 2,91 & 4 & 5 & 0,352 & $\begin{array}{l}\text { Agak } \\
\text { linggi }\end{array}$ \\
\hline 4 & 39,591 & 13,57 & 4,29 & 2 & 1 & 0,159 & Rendah \\
\hline 5 & 42,145 & 14,15 & 1,465 & 4 & 5 & 0,474 & Tinggi \\
\hline 6 & 42,319 & 9,25 & 6,49 & 2 & 1 & 0,117 & Rendah \\
\hline 7 & 17,064 & 4,28 & 2,10 & 2 & 1 & 0,059 & Sangat \\
\hline 8 & 29,994 & 25,81 & 3,65 & 4 & 1 & 0,168 & Rendah \\
\hline 9 & 34,045 & 3,11 & 3,51 & 3 & 5 & 0,343 & $\begin{array}{c}\text { Agak } \\
\text { tinggi }\end{array}$ \\
\hline 10 & 35,902 & 3,10 & 3,49 & 2 & 1 & 0,187 & Rendah \\
\hline li & 31,497 & 5,95 & 4,96 & 2 & 1 & 0,109 & Rendah \\
\hline 12 & 30,045 & 13,15 & 3,56 & 3 & 1 & 0,157 & Rendah \\
\hline
\end{tabular}

Sumber : Hasil analisis laboratorium dan pengamatan lapangan

\section{Topografi}

Faktor topografi yang paling besar pengaruhnya terhadap erosi adalah panjang dan kemiringan lereng. Panjang lereng daerah penelitian berkisar antara 14 meter sampai 61 meter dan kemiringan lereng bervariasi antara 2 $\%$ sampai $40 \%$ yang tergolong datar sampai agak curam men unit klasifikasi kemiringan lereng oleh Arsyad (1989) (Lampiran 4). Hasil perhitungan dengan menggunakan persamaan Wischmeier dan Smith (1978 dalam Arsyad, 1989) didapatkan nilai LS berkisar antara 1,347 sampai dengan 10,213. Nilai LS tertinggi terdapat pada daerah yang diwakili oleh unit lahan no 12 yaitu sebesar 10,213 dan terendah terdapat pada daerah yang diwakili unit lahan no 1 yaitu sebesar 1,347 (Tabel 8).

Kemiringan lereng memberikan pengaruh yang besar terhadap erosi, karena kemiringan lereng mempengaruhi kecepatan limpasan permukaan. Makin tinggi kemiringan iereng maka kesempatan air untuk int'iltrasi semakin kecii sehingga volume limpasan permukaan semakin besar dan erosi yang terjadi juga semakin besar. Panjang lereng juga berperan terhadap besarnya erosi yang terjadi, tetapi pengaruhnya tidak sebesar yang dipengaruhi oleh kemiringan lereng. sehingga makin panjang lereng semakin besar volume aliran permukaan yang terjadi di lereng tersebut.

Tabel 8. Hasil perhitungan faktor panjang lereng dan kemiringan lereng

\begin{tabular}{cccc}
\hline Unit Lahan & Panjang Lereng & Kemringan Lereng (S) ( $)$ & Faktor LS \\
\cline { 2 - 4 } $\mathbf{i}$ & 47 & 2 & 1,347 \\
2 & 32 & 5 & 1,758 \\
3 & 20 & 5 & 1,390 \\
4 & 31 & 7 & 2,149 \\
5 & $\mathbf{1 7}$ & 14 & 2,670 \\
6 & 32 & 9 & 2,607 \\
7 & 61 & 10 & 3,559 \\
8 & $\mathbf{2 9}$ & 20 & 4,691 \\
9 & 31 & 20 & 4,850 \\
10 & 14 & 20 & 3,259 \\
11 & 25 & 40 & 8,234 \\
12 & 40 & 40 & 10,213 \\
\hline
\end{tabular}

\section{Faktor Tanaman dan Pengelolaan Lahan} (CP)

Nilai faktor tanaman dan pengelolaan lahan (CP) didapatkan dengan cara mencocokan keadaan di lapangan dengan nilai CP dari pusat penelitian tanah Bogor pada lahun 1973-1981 dalam Arsyad, (1989) (Lampiran 8-9). Hasil perhitungan nilai $\mathrm{CP}$ pada daerah penelitian disajikan pada tabel 9. 
Nilai CP di daerah penelitian berkisar antara 0,0004 sampai 0,3 . nilai $\mathrm{CP}$ terendah dijumpai pada sawah dengan teras bangku konstruksi baik (unit lahan 8) sedangkan nilai $\mathrm{Cp}$ tertinggi terdapat pada lahan semak belukar tanpa penerapan teknik konservasi tanah (unit lahan 7). Disini teiiihat bahwa semakin banyak tanah yang tertutup pada suatu lahan maka semakin rendah nilai CP nya jadi semakin tinggi kerapatan tanaman maka semakin banyak air hujan yang diintersepsi oleh tajuk tanaman dan semakin banyak permukaan tanah yang terlindungi dari pukulan butiran huajn. Tanaman padi pertumbuhan tanaman sangat rapat, sehingga akarnya dapat menghambat partikel-partikel tanah dan tanaman yang sangat rapat mengurangi energi kinetik hujan, sehingga nilai $\mathrm{CP}$ nya rendah. Potensi erosi akan lebih kecil lagi dengan adanya teras bangku pada lahan tersebut, sebab penterasan akan dapat mengurangi panjang dan kemiringan lereng sehingga memperkecil limpasan permukaan.

Tabel 9- Nilai Faktor Tanaman dan Pengeiolaan (CP)

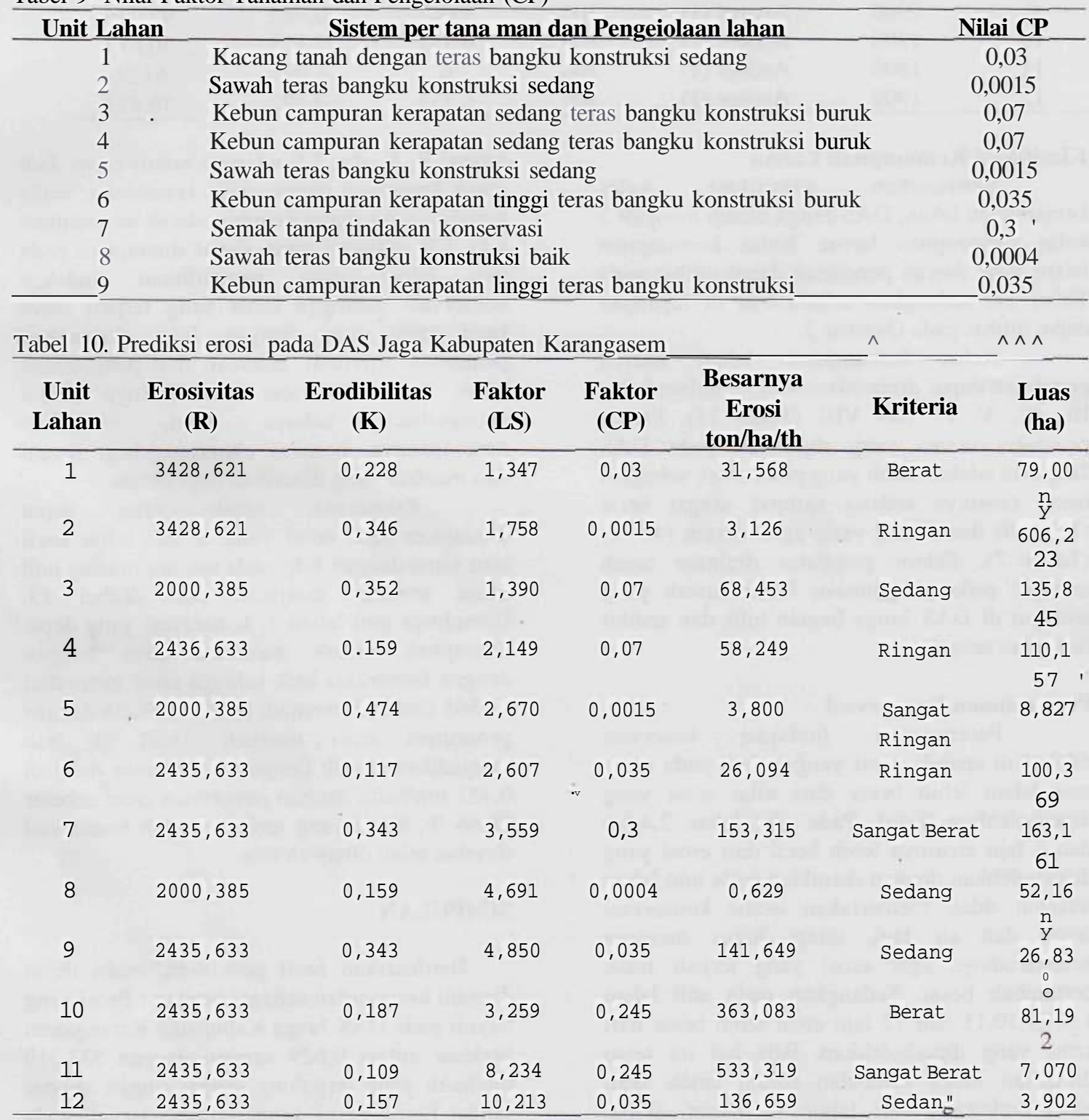

\section{Erosi yang Diperbolehkan}

Hasil perhitungan dengan menggunakan persamaan Hammer (1981), diperoleh nilai Edp yang bervariasi 11,13 sampai 95,63 ton/ha/th (Tabel 10). Perbedaan nilai Edp ini disebabkan karena adanya perbedaan kedalaman tanah dan berat volume tanah pada setiap unit lahan. Nilai Edp tertinggi pada unit lahan 7 sedangkan nilai terendah pada unit lahan 6 . 
Tabel 11. Nilai Erosi yang Diperbolehkan

\begin{tabular}{ccccccc}
\hline $\begin{array}{c}\text { Unit } \\
\text { Lahan }\end{array}$ & $\begin{array}{c}\text { Kedalaman } \\
\text { tanah (mm) }\end{array}$ & $\begin{array}{c}\text { Faktor } \\
\text { kedalaman }\end{array}$ & $\begin{array}{c}\text { Kelestarian } \\
\text { tanah }(\mathbf{t h})\end{array}$ & $\begin{array}{c}\text { Edp } \\
(\mathbf{m m} / \mathbf{t h})\end{array}$ & $\begin{array}{c}\text { Berat volume } \\
\left(\mathbf{g} / \mathbf{c n r}^{\mathbf{1}}\right)\end{array}$ & $\begin{array}{c}\text { Edp } \\
\text { (ton/ha/th) }\end{array}$ \\
\hline $\mathbf{1}$ & 480 & Andept fl) & 300 & 1.6 & 1,230 & 19,68 \\
$\mathbf{2}$ & 900 & Andept (1) & 300 & 3 & 0,958 & 28,74 \\
$\mathbf{3}$ & 1400 & Andept (1) & 300 & 4,667 & 1,375 & 64,167 \\
$\mathbf{4}$ & 1600 & Andept (1) & 300 & 5,333 & 0,913 & 48,693 \\
$\mathbf{5}$ & 2500 & Andept (1) & 300 & 8,333 & 1,200 & 100 \\
$\mathbf{6}$ & 2900 & Andept (1) & 300 & 9,667 & 0,989 & 95,603 \\
$\mathbf{7}$ & 250 & Andept (1) & 300 & 0,833 & 1,336 & 11,133 \\
$\mathbf{8}$ & 550 & Andept (1) & 300 & 1,833 & 1,109 & 20,331 \\
$\mathbf{9}$ & 2900 & Andept (1) & 300 & 9,667 & 0,952 & 92,026 \\
10 & 1900 & Andept (1) & 300 & 6,333 & 1,115 & 70,617 \\
11 & 1800 & Andept (1) & 300 & 6 & 1,021 & 61,26 \\
12 & 1900 & Andept (1) & 300 & 6,333 & 0,892 & 56,433 \\
\hline
\end{tabular}

\section{Klasifikasi Kemampuan Lahan}

Berdasarkan klasifikasi kelas kemampuan lahan, DAS Janga dibagi menjadi 5 kelas kemampuan lahan. Kelas kemampuan lahan pada daerah penelitian dapat dilihat pada Tabel 12, sedangkan sebarannya di lapangan dapat dilihat pada Gambar 3.

Kelas kemampuan lahan daerah penelitian dapat diklasifikasikan ke dalam kelas III, IV, V, IV dan VIII (Tabel 11). Faktor pembatas utama yang diperoleh pada DAS Janga ini adalah tanah yang peka erosi, sebagian besar erosinya sedang sampai sangat berat (Tabel 9) dan lereng yang agak curam (40\%) (Tabef 7). Faktor pembatas drainase tanah terdapat pada penggunaan lahan sawah yang terdapat di DAS Janga bagian hilir dan sedikit di bagian tengah.

\section{Perencanaan Konservasi}

Perencanaan tindakan koservasi dilakukan apabila erosi yang terjadi pada suatu unit lahan lebih besar dari nilai erosi yang diperbolehkan (Edp). Pada unit lahan 2,4,5,6 dan 8 laju erosinya lebih kecil dari erosi yang diperbolehkan dengan demikian pada unit lahan tersebut tidak memerlukan usaha konservasi tanah dan air tagi, tetapi harus menj aga kelestariannya agar erosi yang terjadi tidak bertambah besar. Sedangkan pada unit lahan 1,3,7,9,10,11 dan 12 laju erosi lebih besar dari erosi yang diperbolehkan. Bi!a hal ini tetap dibiarkan maka ketebalan solum tanah akan terus berkurang dari tahun ke tahun, akibat selanjutnya akan terjadi kerusakan lingkungan dan penurunan produktivitas tanah. Berdasarkan Persamaan Umum Kehilangan Tanah, maka faktor-faktor penyebab erosi yang dapat diubah adalah tanaman (C) dan pengelolaan lahan (P), sedangkan faktor-faktor penyebab yang lain seperti R, K, dan LS nilainya relatif tetap. Jadi untuk keperluan perencanaan konservasi, maka tindakan yang dapat diambil adalah menetapkan niiai $\mathrm{CP}$ tertinggi yang dapat diterapkan pada unit lahan yang memerlukan ti ndakan konservasi sehingga erosi yang terjadi lebih kecil atau sama dengan Edp. Sedangkan pemilihan alternatit" tanaman dan pengelolaan lahan didasarkan atas efektifitasnya dalam memperkecil bahaya erosi, kemudian penerapannya, bernilai ekonomis bagi petani dan manfaat yang dibeokan bagi petani.

Konservasi tanah yang dapat diterapkan agar erosi yang terjadi lebih kecil atau sama dengan Edp pada masing-masing unit lahan tersebut disajikan pada Tabel 13. Contohnya unit lahan 1, konservasi yang dapat diterapkan adalah membuat teras bangku dengan konstruksi baik sehinga erosi turun dari 31,568 ton/ha/th menjadi 8,423 ton/ha/th dengan penurunan eros $\mathrm{i}$ menj adi 73,31 \% atau menjadikan sawah dengan teras turun menjadi 0,421 ton/ha/th dengan penurunan erosi sebesar 98,66 \%. Erosi yang terjadi setelah konservasi tersebut telah dibawah Edp.

\section{SIMPULAN}

Berdasarkan hasil penelitian, maka dapat diambil kesimpulan sebagai berikut: Erosi yang terjadi pada DAS JangaKabupaten Karangasem berkisar antara 0,629 samapi dengan 533,319 ton/ha/th yang tergolong sangat ringan sampai sangat berat. Erosi sangat ringan terjadi pada unit lahan 5 seluas 8,827 ha $(0,54 \%)$. Erosi ringan terdapat pada unit lahan 2,4 dan 6 seluas 816,74 ha $(50,21 \%)$. Erosi sedang terdapat pada unit lahan $3,8,9$ dan 12 seluas 218,75 ha $(21,83$ $\%)$. Erosi berat terjadi pada unit lahan 1 dan 10 seluas 156,20 ha $(9,6 \%)$. Erosi sangat berat 
terjadi pada unit lahan 7 dan 11 sehias 170,23 yang terjadi lebih kecil dari erosi yang diperbolehkan (Edp), oleh karena itu pada unit lahan tersebut harus melestarikan konservasi yang sudah ada, sedangkan unit lahan $1,3,7,9,10,11$ dan 12 erosi yang terjadi lebih besar dari erosi yang diperboiehkan (Edp) sehingga perlu dilakukan tindakan konservasi. Klasifikasi kemampuan lahan pada DAS Janga dapat digolongkan ke dalam kelas III, IV, V, VI dan VIII. Faktor pembatasnya adalah kepekaan erosi, lereng yang agak curam, serta drainage yang agak buruk. Konservasi yang dapat diterapkan adalah dengan menambah kerapatan tanaman, penanaman menurut garis kontur dan atau merubah teras dari teras bangku konstruksi buruk menjadi teras bangku konstruksi baik.

\section{UCAPAN TERIMA KASIH}

Pada kesempatan ini penulis yang baik ini perkenankan penulis untuk mengucapkan terima kasih yang tak terhingga kepada Bapak Ir. I Wayan Diara, MS dan Ibu Ir. Wiyanti, MP atas bimbingan beliau selama penyusunan tulisan ini.

\section{DAFTAR PUSTAKA}

Adnyana,S. Dkk. 1999. Penuntun Praktikum Konservasi Tanah dan Air. Jurusan Tanah Fakultas Pertanian Universitas Udayana. Denpasar

Arsyad, S. 19.85. Strategi Konservasi Tanah. Lokakarya Pengelolaan Daerah Aliran Sungai Terpadu. Penyelenggara UGM dan DISHUTBUN

Arsyad S. 1989. Konservasi Tanah dan Air. IPB. Bogor

Diara, W. dkk. 2001. Diktat Konservasi Tanah dan Air. Jurusan Ilmu Tanah Fakultas Pertanian Universitas. Udayana. Denpasar

Hardjowigeno, S. 2003. Ilmu. Tanah. Akademika Pressindo. Jakarta

Kartasapoetm,G. Sutejo,M. 1985. Teknologi Konservasi Tanah dan Air. Rineka Cipta. Jakarta

Sarief, S. 1988. Konservasi Tanah an Air. Pustaka Buana Bandng

Soetejo. Kartasapoetra, A.G. 2002. Pengantar Ilmu Tanah. Bineka Cipta. Jakarta

Utomo, W.H. 1987. Erosi dan Konservasi Tanah. Universitas Brawijaya. Malang 